\title{
IDENTIFIKASI PERAWAT PROFESIONAL DALAM MENERAPKAN \\ PROSES DOKUMENTASI PENGAMBILAN KEPUTUSAN DAN \\ DIAGNOSA KEPERAWATAN PADA PASIEN DI RUMAH SAKIT
}

NOVITA SARI

$\underline{\text { novitampii1212@gmail.com }}$

\begin{abstract}
ABSTRAK
Diagnosis Keperawatan merupakan keputusan klinik tentang respon individu, keluarga dan masyarakat tentang masalah kesehatan aktual atau potensial, dimana berdasarkan pendidikan dan pengalamannya, perawat secara akontabilitas dapat mengidentifikasi dan memberikan intervensi secara pasti untuk menjaga, menurunkan, membatasi, mencegah danmerubah status kesehatan klien. NANDA Menyatakan bahwa diagnosa keperawatan adalah "keputusan klinik tentang respon individu ,keluarga dan masyarakat tentang masalah kesehatan actual atau potensial ,sebagai dasar seleksi intervensi keperawatan untuk mencapai tujuan asuhan keperawatan sesuai dengan kewenangan perawat "semua diagnosa keperawatan harus didukung oleh data ,dimana menurut NANDA diartikan sebagai"definisi karaktristik "definisi karakterristik di namakan "tanda dan gejalah "tanda adalah suatu yang dapat diobossitas dan gejalah adalahb sesuatu yang di rasakan oleh klien. Tujuan: Untuk mengetahui proses dan model-model pengambilan keputusan dengan konsep berfikir kritis agar dapat meningkatkan kemampuan dan ketrampilan perawat dalam pengambilan keputusan. Pengambilan keputusan tidak dilakukan secara sembrono tapi harus berdasarkan pada sistematika tertentu. Metode: Metode penulisan ini adalah Literature Riview, dimana ini menganalisis artikel yang relevan dan berfokus pada tema.
\end{abstract}

kata kunci : Identifikasi Perawat, Dokumentasi,Pengambilan Keputusan Dan Diagnosa Keperawatan.

\section{LATAR BELAKANG}

Diagnosis Keperawatan merupakan berdasarkan pendidikan dan keputusan klinik tentang respon individu, pengalamannya, perawat secara keluarga dan masyarakat tentang masalah akontabilitas dapat mengidentifikasi dan kesehatan aktual atau potensial, dimana memberikan intervensi secara pasti untuk 
menjaga, menurunkan, membatasi, mencegah dan merubah status kesehatan klien. Diagnosis keperawatan ditetapkan berdasarkan analisis dan interpretasi data yang diperoleh dari pengkajian keperawatan klien.

Diagnosis keperawatan memberikan gambaran tentang masalah atau status kesehatan klien yang nyata (aktual) dan kemungkinan akan terjadi, dimana pemecahannya dapat dilakukan dalam batas wewenang perawat.Proses keperawatan telah diidentikan sebagai metoda ilmiah keperawatan untuk para penerima tindakan keperawatan. Kebanyakan sekolah-sekolah keperawatan sekarang memasukkan proses keperawatan sebagai sautu komponen dari konsep kerja konsepatual mereka.

Perawat merupakan profesi kesehatan yang terpenting dirumah sakit selain karna jumlahnya yang lebih dominan juga karena merupakan profesi yang memberikan pelayanan kesehatan secara konstan dan terus menerus selama 24 jam setiap hari kepada klien.Sehingga setiap upaya untuk meningkatkan kualitas pelayanan rumah sakit harus juga disertai upaya untuk meningkatkan kualitas pelayanan keperawatan (Yani, 2007).

Asuhan keperawatan bermutu dapat meningkatkan kemampuan berfikir kritis perawatdalam melakukan pelayanannya.
Pelayanan keperawatan didasarkan dengan pendekatan pengambilan keputusan yang ditingkatkan dengan berfikir kritis (Ignatavicus \&Workman, 2006). Berfikir kritis menurut Sullivan E.J Decker P.J (2001) adalah suatu proses untuk memeriksa berdasarkan pada asumsi, iterpretasi, evaluasi argumentasi,imanjinasi dan eksplorasi alternatif serta mengembangkan refleksi yang kritis untuk mendapatkan kesimpulan sebagai suatu alasan dan justifikasi. Berfikir krtis keperawatan merupakan perpaduan antara pengetahuan, perilaku dan ketrampilan yang dimiliki perawat dalam menganalisa keadaan.

Hubungan perawat klien adalah dasar dari praktik keperawatan yang berfokus pada pasien (patient centered care). Keterlibatan pasien merupakan inti dari proses keperawatan, sehingga partisipasi pasien dalam proses keperawatan menjadi penting dalam penentuan kualitas dan efektifitas dalam pelayanan asuhan keperawatan.

Pemberian asuhan keperawatan harus berdasarkan nilai-nilai dan etika yang dianut oleh klien dan nilai-nilai profesional asuhan keperawatan. Mengkombinasikan nilai profesional, etik dan nilai yang di anut klien akan meningkatkan pelayanan, identifikasi kebutuhan dan masalah keperawatan lebih sistematis sehingga meningkatkan pemahaman klien dalam 
pengambilan keputusan asuhannya (Doheni. 1992, Potter. 2005, Jan florin. 2007).

Proses pengambilan keputusan klinis merupakan komponen penting dalam proses keperawatan (Diana Catarina, 2009), sehingga dibutuhkan kemampuan perawatan karena Keterbatasan pengetahuan dan kemampuan yang dimiliki perawat dapat menghambat perawat dalam mengambil keputusan mengenai perawatan yang akan diberikan kepada klien yang akan berakibat fatal terhadap klien (Kozier et al, 2010).

Keputusan klinis adalah suatu proses yang meliputi diagnosis klinis, penilaian dan keputusan tentang apa yang harus dilakukan (Ennis 1996). Proses pengambilan keputusan dalam praktik klinik keperawatan dipahami sebagai serangkaian keputusan yang dibuat oleh perawat dalam interaksinya dengan pasien mengenai jenis pengamatan yang akan dilakukan dalam situasi yang di alami klien (pengkajian keperawatan), perumusan diagnosa keperawatan, rencana tindakan keperawatan yang harus diambil, tindakan keperawatan yang akan diambil serta evaluasi (Dianan Catarina. 2009, Jan Florin. 2007, Mehee, 2014).

\section{TUJUAN}

Untuk mengetahui proses dan model-model pengambilan keputusan dengan konsep berfikir kritis agar dapat meningkatkan kemampuan dan ketrampilan perawat dalam pengambilan keputusan. Pengambilan keputusan tidak dilakukan secara sembrono tapi harus berdasarkan pada sistematika tertentu. Keputusan yang baik adalah keputusan yang telah dipilih dari berbagai alternatif yang telah dianalisa secara matang. Pengambilan keputusan ini bertujuan untuk memilih pilihan yang tepat agar mencapai hasil yang terbaik sesuai kondisi dan prioritas masalah klien.

\section{METODE}

Metode penulisan ini adalah Literature Riview, dimana ini menganalisis artikel yang relevan dan berfokus pada tema yaitu Proses Pengambilan Keputusan Dan Diagnosa Keperawatan Pada Pasien dan pada kajian ini adalah metode kualitatif yang memberikan penjelasan dengan menggunakan analisis pada referensirefensi yang digunakan. Adapun sumber yang digunakan dalam literature ini menggunakan sumber dari buku teks dan jurnal dengan memasukan kata kunci pelaksanaan tahap Perencanaan dalam proses keperawatan. Adapun jurnal yang saya gunakan merupakan jurnal yang diterbitkan pada 8 tahun terakhir.

\section{HASIL}


Ketepatan pengambilan keputusan akan di pengaruhi oleh kompentisi perawat, kemampuan berkomunikasi, lingkungan serta budaya. Penting bagi perawat untuk selalu meningkatkan kapasitas dirinya dalam pemberian asuhan keperawatan hal ini akan meningkatkan kepercayaan masyarakat terhadap perawat yang selanjutnya akan meningkatkan profesionalisme perawat.

Hal ini bisa digunakan sebagai acuan dalam melakukan hubungan interdisiplin. Pengambilan keputusan yang tepat akan meningkatkan kemandian klien dalam asuhannya serta membantu klien untu menentukan pilihan bantuan yang tepat sesuai dengan kondisinya.

Klien yang mandiri akan menurunkan beban kerja perawat sehingga pelayanan keperawatan akan lebih efektif dan efisien dalam penggunaan sumber daya. Untuk itu dibutuhkan banyak dukungan dalam implementasi shared clinical decision making ini, misal dibuatkannya SPO pengambilan keputusan klinis keperawatan, meningkatkan sumber daya perawat dengan menciptakan perawat yang caring perawat yang peka budaya perawat memperhatikan etik, disiplin danbioteik keperawatn dalam setiap asuhahhnya sebagai upaya untuk meningkatkan kemampuan berkomunikasi memberikan dukungan kepada pasien, sehingga dubutuhkan PKB (Pendidikan
Keperawatan Berkelanjutan) atau dengan sistem preseptorship untuk membentuk perawat yang kompeten, mempunyai kemampuan critical thinking dalam pengambilan keputusan klinis keperawatan.

Misalnya: Hasil pengkajian diperoleh data klien mual, muntah, diare dan turgor jelek selama 3 hari. Diagnosa: Kekurangan volume cairan tubuh berhubungan dengan kehilangan cairan secara abnormal. 2. Risiko Diagnosa Keperawatan Risiko menjelaskan masalah kesehatan yang nyata akan terjadi jika tidak dilakukan intervensi. Syarat menegakkan risiko diagnosa keperawatan adanya unsur PE (problem dan etiologi).Penggunaan istilah "risiko dan risiko tinggi" tergantung dari tingkat keparahan/kerentanan terhadap masalah. Diagnosa: "Risiko gangguan integritas kulit berhubungan dengan diare yang terus menerus". 3. Kemungkinan Diagnosa Keperawatan Kemungkinan menjelaskan bahwa perlu adanya data tambahan untuk memastikan masalah keperawatan kemungkinan.Pada keadaan ini masalah dan faktor pendukung belum ada tapi sudah ada faktor yang dapat menimbulkan masalah.Syarat menegakkan kemungkinan diagnosa keperawatan adanya unsur respons (Problem) dan faktor yang mungkin dapat menimbulkan masalah tetapi belum ada. Contoh: Diagnosa: Kemungkinan gangguan konsep diri: 
rendah diri/terisolasi berhubungan dengan diare. Perawat dituntut untuk berfikir lebih kritis dan mengumpulkan data tambahan yang berhubungan dengan konsep diri. 4 . Diagnosa Keperawatan "Wellness" Diagnosa keperawatan wellness (sejahtera) adalah keputusan klinik tentang keadaan individu, keluarga, dan atau masyarakat dalam transisi dari tingkat sejahtera tertentu ke tingkat sejahtera yang lebih tinggi. Ada 2 kunci yang harus ada: 1) Sesuatu yang menyenangkan pada tingkat kesejahteraan yang lebih tinggi 2) Adanya status dan fungsi yang efektif.

Organisasi profesi mempunyai peranan yang penting dalam mewujudkan perawat yang kompeten dalam melakukan pengambilan keputusan klinis keperawatan.

\section{PEMBAHASAN}

Diagnosa keperawatan dapat dibedakan menjadi 5 kategori:

(1) Aktual, (2) Resiko, (3) Kemungkinan, (4) Keperawatan welness, (5) Keperawatan Sindrom.

1. Aktual Diagnosa Keperawatan aktual menjelaskan masalah nyata saat ini sesuai dengan data klinik yang ditemukan.Syarat menegakkan diagnosa keperawatan aktual harus ada unsur PES.Symptom (S) harus memenuhi kriteria mayor dan sebagian kriteria minor dari pedoman diagnosa NANDA.
Misalnya: Hasil pengkajian diperoleh data klien mual, muntah, diare dan turgor jelek selama 3 hari. Diagnosa: Kekurangan volume cairan tubuh berhubungan dengan kehilangan cairan secara abnormal. 2 . Risiko Diagnosa Keperawatan Risiko menjelaskan masalah kesehatan yang nyata akan terjadi jika tidak dilakukan intervensi. Syarat menegakkan risiko diagnosa keperawatan adanya unsur PE (problem dan etiologi).Penggunaan istilah "risiko dan risiko tinggi" tergantung dari tingkat keparahan/kerentanan terhadap masalah. Diagnosa: "Risiko gangguan integritas kulit berhubungan dengan diare yang terus menerus".

\section{Kemungkinan Diagnosa Keperawatan} Kemungkinan menjelaskan bahwa perlu adanya data tambahan untuk memastikan masalah keperawatan kemungkinan.Pada keadaan ini masalah dan faktor pendukung belum ada tapi sudah ada faktor yang dapat menimbulkan masalah.Syarat menegakkan kemungkinan diagnosa keperawatan adanya unsur respons (Problem) dan faktor yang mungkin dapat menimbulkan masalah tetapi belum ada. Contoh: Diagnosa: Kemungkinan gangguan konsep diri: rendah diri/terisolasi berhubungan dengan diare. Perawat dituntut untuk berfikir lebih kritis dan mengumpulkan data tambahan yang berhubungan dengan konsep diri. 
4. Diagnosa Keperawatan "Wellness" Diagnosa keperawatan wellness (sejahtera) adalah keputusan klinik tentang keadaan individu, keluarga, dan atau masyarakat dalam transisi dari tingkat sejahtera tertentu ke tingkat sejahtera yang lebih tinggi.

Ada 2 kunci yang harus ada:

1) Sesuatu yang menyenangkan pada tingkat kesejahteraan yang lebih tinggi

2) Adanya status dan fungsi yang efektif.

Langkah-langkah dalam penulisan diagnosa keperawatan terdiri dari:

1. Pengelompokan Data dan Analisa data a. Data Subjektif Contoh: "Pasienmengeluhkan nyeri saat menelan karena ada tumor di leher, akibatnya BB turun lebih dari $10 \mathrm{~kg}$ dalam 12 bulan berakhir, karena nyeri menelan.” b. Data Objektif Contoh: $\mathrm{TB}=165 \mathrm{~cm}, \mathrm{BB}=45 \mathrm{~kg}$

2. Interpretasi Data Contoh: Gangguan pemenuhan nutrisi kurang dari kebutuhan tubuh.

\section{Validasi Data}

Validasi data ini dilakukan untuk memastikan ke akuratan diagnosa dimana perawat bersama pasien memvalidasi diagnosa sehingga diketahui bahwa pasien setuju dengan masalah yang sudah dibuat dan faktor-faktor yang mendukungnya.
Contoh: Perawat mengukur BB pasien akibat tumor yang dideritanya.

4. Penyusunan Diagnosa Keperawatan (dengan rumusan $\mathrm{P}+\mathrm{E}+\mathrm{S}$ ) $\mathrm{P}=$ Problem $\mathrm{E}=$ Etiolog $\mathrm{S}=$ Symptom. Contoh: Gangguan pemenuhan nutrisi: kurang dari kebutuhan tubuh berhubungan dengan intake yang tidak adekuat ditandai dengan klien mengatakan $\mathrm{BB}$ turun lebih dari $10 \mathrm{~kg}$ dalam 12 bulan terakhir, TB $=165 \mathrm{~cm}, \mathrm{BB}$ $=45 \mathrm{~kg}$.

Dari contoh diagnosa di atas, dapat diketahui:

- Problemnya adalah: gangguan pemenuhan nutrisi kurang dari kebutuhan tubuh.

- Etiologinya adalah: intake yang tidak adekuat.

- Symptomnya adalah: klien mengatakan BB turun lebih dari $10 \mathrm{~kg}$ dalam 12 bulan terakhir, klien mengeluh nyeri saat menelan, sehinggan menghindari untuk tidak makan, $\mathrm{TB}=170 \mathrm{~cm}, \mathrm{BB}=50 \mathrm{~kg}$.

Inti dari dokumentasi adalah proses keperawatan. Sehingga kualitas dokumentasi keperawatan merupakan cermin dari keberhasilan asuhan dalam proses keperawatan (Jan Florin 2007). Dokumentasi keperawatan meliputi permusan diagnosa keperawatan, tujuan, rencana tindakan, implementassi dan 
evaluasi. Sesuai dengan standar disiplin profesi pendokumentasian dan pelaksanaan tersebut harus sesuai dengan standar yang telah ditetapkan yaitu harus memenuhi standar sebagai berikut:

1. Pengkajian Keperawatan dilakukan berdasarkan standart pengkajian yang digunakan dalam rumah sakit yang bersangkutan dan dilakukan dokumentasi sesuai dengan standart yang ada.

2. Diagnosa adalah sebuah keputusan dan sekaligus sebagai hipotesis terhadap masalah yang dihadapi oleh pasien selama dilakukan perawatan dirumah sakit. Data pasien harus divalidasi atau reasesment setiap hari, sehingga diagnosa menyesuaikan data yang ditemukan pada hari itu karena diagnosa keperawatan adalah respon dimana kemungkinan respon setiap hari berubah. Jika respon pasien berubah maka diagnosa keperawatanpun akan berubah pula.

3. Perencanaan merupakan suatu langkah sitematis untuk mengatasi masalah keperawatan sesuai dengan tujuan yang diharapkan. Jika diagnosa berubah maka intervensi harus mengikuti diagnosa yang muncul dan terdokumentasi.

\section{Implementasi Keperawatan merupakan tindakan yang dilakukan oleh seoarang perawat berdasarkan intervensi/ rencana keperawatan. Dalam pelaksanaannya harus}

ada Standar Prosedur Operasional (SPO) atau panduan dalam melakukan implementasi.

5. Evaluasi adalah validasi terus menerus menerus terhadap pencapaian tujuan keperawatan berdasarkan diagnosa yang di ambil. Pemberian asuhan keperawatan harus memeperhatikan klien dengan memberikan penghargaan individu meliputi preferensi, keperluan, nilai-nilai, dan memastikan bahwa semua pengambilan keputusan klinik telah mempertimbangkan dari semua nilai-nilai yang diingini pasien (Comite if quality of health institute of medicine 2001).

Pengambilan Keputusan Klinis Keperawatan

Beberapa konsep yang digunakan untuk menggambarkan berpikir kritis dalam keperawatan adalah penalaran klinis, perumusan diagnostik, pengambilan keputusan, penilaian, dan pemecahan maslah. Menurut penelitian yang dilakukan oleh Panggabean, 2019 kemampuan berfikir kritis perawat dalam pengambilan keputusan klinis berhubungan erak dengan kemampuan berfikir kritis perawat dengan nilai $\mathrm{p}=0,026$ dan juga menurut Khairina, 2018 pengalaman kerja mempunyai hubungan erat dengan kemampuan pengambilan keputusan klinis dengan nilai $\mathrm{p}$ value 0,012 . Berpikir kritis digambarkan 
sebagai "sebuah proses, tujuan untuk membuat keputusan yang masuk akal tentang apa yang harus percaya dan apa yang harus dilakukan". Pengambilan keputusan klinis adalah sebuah proses yang melibatkan kedua penalaran diagnostik dan penilaian klinis. Tindakan dalam ini tindakan diarahkan sebagai proses refleksi dari perawat maupun pasien (Jan Florin, 2007).

Pengambilan keputusan sangat penting keberadaannya dalam asuhan maupun dalam manajemen keperawatan. Pengambilan keputusan merupakan suatu proses yang mencakup semua penilaian kegiatan yang diperlukan guna membuktikan dan meperlihatkan pilihan terbaik dalam menyelesaiakan suatu masalah tertentu. setiap keputusan adalah akibat dari sebuah proses dinamis yang dipengaruhi oleh banyak kekuatan, pengambilan keputusana bukan merupakan prosedur yang tetap akan tetapi sebuah proses yang beruntun. pengambilan keputusan adalah proses yang melibatkan pendekatan sistemik yang harus diadaptasikan dengan lingkungan.

Bagaimanan perawat dalam mengambil keputusan klinis? Pengambilan keputusan keperawatan dilakukan pada semua tahap proses keperawatan. Sehingga seorang perawat harus mampu berpikir ktitis, berkomunikasi dengan baik sebagai suatu elemen penting dalam pengaambilan keputusan klinis, sehingga terjadi pembelajaran berkelanjutan bagi pasien sehingga meningkatkan tingkat kemandirian pasien.

Pengambilan keputusan merupakan sebuah pola tertentu sama halnya dengan proses keperawatan, jelas bahwa dalam setiap proses keperawatan perawat harus mampu mengambil keputusan klinis. Sedangkan menutut Guyatt (Agung pranoto. 2013) menjelaskan bahwa asuhan yang berdasarkan evidence base pengambilan keputusan harus melibatkan pasien. Sehingga penting bagi perawat untuk mampu mengambil keputusan dengan baik, cepat dan akurat dalam hal ini menurut Sumijatun (Samijatun 2009) perlu dipahami bagi perawat bahwa pengambilan keputusan klinis dengan melibatkan klien akan erat hubungannya dengan nilai-nilai budaya yang dianut oleh klien.

Partisipasi Klien Dalam Pengambikan Keputusan Klinis Keperawatan

Membantu klien dalam pengambilan keputusan klinis membutuhkan ketepampilan teknis, interpersinal, intelektual dan berlandaskan etika keperawatan selain itu diperlukan wawasan terhadap masalah-masalah lain yang terkait dan juga perlu adanya latihan khusus bagi perawat untuk belajar mengambil 
keputusan klinis terkait dengan konsep terkait (Samijatun, 2009). Hubungan perawat-klien adalah suatu hubungan interpersonal yang profesional dan terapeutik dengan tujuan memenuhi kebutuhan klien. Hubungan profesional perawat dan klien didasarkan pada pemahaman bahwa klien adalah orang yang paling tepat untuk membuat keputusan. Peran utama tim kesehatan adalah memfasilitasi dan memberdayakan potensi internal klien. Dengan demikian, hubungan yang terjadi haruslah menguntungkan klien dan tidak memiliki efek yang negatif bagi klien.

Dalam pengambilan keputusan seorang perawat harus berlandaskan etika praktik keperawatan yang berdasarkan pada pemikiran kritis dan reflektif mengenai tanggung jawab dan kewajiban seorang perawat terhadap klien ( Jan Florin, 2007 dan Fakultas Ilmu Keperawatan Universitas Padjajaran, 2013). Kolaborasi perawat klien merupakan komponen utama dalam pemberian asuhan keperawatan, pengambilan keputusan merupakan bagian dari asuhan keperawatan, sehingga pengambilan keputusan dalam proses keperawatan harus melibatkan pasien dan keluarganya.

Keterlibatan klien yang dimaksud dalam pengambilan keputusan ini adalah sebagai upaya pemberdayaan klien sehingga meningkatka tingkat kemandirian klien sebagaimana dijelaskan dalam teori Dorothea Orem (1980): self care dimana konsep ini menekankan pada perawatan diri secara mandiri, kemandirian dipandang sebagai bentuk praktik kebiasaan/tingkah laku yang dilakukan oleh klien dalam mepertahankan kesehatan dan kondisinya (Jaan Florin 2007, Samijatun 2009 dan Aligood, 2012).

Tingkat kemandirian ini akan dicapai jika pasien dan keluarga mampu mengambil keputusan dengan baik dan tepat dalam memilih assuhan dan bantuan terkait kondisinya. Sehingga diperlukan peran aktif pasien dan keluarga daalam pengambilan keputusan klinis tersebut. Dalam beberapa penilitian disebutkan bahwa tugas perawat pada saat pengambilan proses pengambilan keputusan ini adalah sebagai fasilitator untuk memberikan fasilitas dan dukungan pada klien (Jan Florin 2007 dan paaulina Bravo. 20115).

Pengambilan keputusan ini jika merujuk pada teori adaptasi amaka kan didapat setelah klien mamu beradapsi dengan lingkungan dalam hal ini lingkungan perawatan klien. Perawat harus mampu memberikan fassilitas buat klien untuk mampu mepelajari lingkungan perawatan reflektif learning harus ditepkan oleh perawat kepada pasien. Tanggung jawab 
utama saat membina hubungan kolaborasi perawat-klien adalah bahwa perawat berperan seebagai leader dalam pengambilan keputusan klinis keperawatan. Pengalam pasien dalam keterlibatan proses keperawatan harus dihargai dan dapat digunakan sebagai dasar dalam pengambilan keputusan klinis. Perawat harus memahami kebutuhan klien dalam setiap proses keperawatan, sehingga hubungan perawat klien dalam pengambilan keputusan dalam dilakukan.

\section{PENUTUP}

Penerapan proses dokumentasi pengambilan keputusan dan diagnosa keperawatan dengan pedoman untuk meningkatkan derajat kesehatan bagi pasien dan juga Peningkatan pengetahuan dan kinerja seorang perawat dimulai dari pemahaman, pengasuhan terhadap memandirikan pasien dan memberi peran keluarga pasien untuk dapat mengetahui apa yang baik untuk si pasien dan bagi perawat untuk dapat menguasai konsep dasar keperawatan maupun proses keperawatan untuk menciptakan perawat profesional.

\section{DAFTAR PUSTAKA}

Apriyani, Heni. (2015). Identifikasi Diagnosis Keperawatan Pada Pasien Di Ruang Paru Sebuah Rumah Sakit.
Jurnal Keperawatan, XI (1), 107109. ISSN $1907-0357$

Deniati, dkk. (2018). Pengaruh Berfikir Kritis Terhadap Kemampuan Perawat Pelaksana Dalam Melakukan Asuhan Keperawatan di Rumah Sakit Hermina Bekasi Tahun 2016. Jurnal Kesehatan Holistik, 12(1), 21-24

Dewi. Rosmalia, R. A. (2014). Analisis Sistim Manajemen Dokumentasi Keperawatan pada Poliklinik Gigi Rumah Sakit di Bukittinggi. Jurnal Kesehatan Andalas. 3(1), 967-968.

Fathi, A, A \& Simamora, R.H. (2019, March). Investigating nurses' coping strategies in their workplace as an indicator of quality of nurses' life in Indonesia: a preliminary study. In IOP Conference Series: Earth and Environmental Science (Vol.248, No.1, p.012031). IOP Publishing.

Hastuti, W. (2017). Aplikasi Concept Mapping Dalam Pemberian Asuhan Keperawatan di Stase Maternitas. Jurnal Keperawaran dan Pemikiran Ilmiah, 3(3), 19-22

Heni. (2017). Berfikir Kritis Dalam Proses Keperawatan. Jurnal Keperawatan, 3(1), 26-29

Kiki. Deniati, R. A. (2018). Pengaruh Berfikir Kritis Terhadap Kemampuan 
Perawat Pelaksana Dalam Melakukan Asuhan Keperawatan Di Rumah Sakit Hermina Bekasi Tahun 2016. Jurnal Kesehatan Holistik (The Journal of Holistic Healthcare. 12(2), 21-25.

Patmawati, dkk. (2018). Efektifitas Metode Pembelajaran Klinik Terhadap Kemampuan Berfikir Kritis dan Kepercayaan Diri Mahasiswa Keperawatan. Jurnal Keperawatan Muhammadiyah, 3(2), 89-92

Rachmania, D. (2016). Pengembangan Instrument Diagnosis \& Intervensi Keperawatan Berbasis Standardized Nursing Language (NANDA-I, NOC,NIC). Jurnal Ners, 11(2)

Simamora, R. H., Bukit, E., Purba, J. M., \& Siahaan, J. (2017). Penguatan kinerja perawat dalam pemberian asuhan keperawatan melalui pelatihan ronde keperawatan di rumah sakit royal prima medan. Jurnal pengabdian kepada masyarakat, 23(2), 300-304.

Simamora, R. H. (2019). Socialization of Information Technology Utilization and Knowledge of Information System Effectiveness at Hospital Nurses in Medan, North Sumatra. Editorial Preface From the Desk of Managing Editor ..., 10(9).

Sudono, dkk. (2017). Gambaran Kemampuan Berfikir Kritis Perawat Primer Dalam Pelaksaan Asuhan Keperawatan di Rumah Sakit Islam Surakarta. Jurnal Ilmu Keperawatan Indonesia,10(1), 81-84

Wulandari, Anggraeni \& Noor. (2014). Gambaran Proses Pengambilan Keputusan Pasien Rawat Jalan RSIA Sitti Khadijah 1 Makassar. Tesis tidak dipublikasikan. Fakultas Kesehatan Masyarakat UNHAS. 